\title{
Metastase Giant Cell Tumour of Bone ke Paru
}

\author{
Dutia Gestin ${ }^{1}$, Aswiyanti Asri², Hera Novianti²
}

\section{Abstrak}

Giant-cell tumor of bone (GCT) merupakan tumor tulang primer yang biasa terjadi pada dewasa muda usia 20-40 tahun. Giant-cell tumor of bone bersifat jinak tapi sangat destruktif lokal dan memiliki rekurensi yang sangat tinggi. Metastase GTC of bone ke paru sangat jarang, dengan angka kejadian 1-9\% dari seluruh kasus. Belum ada penjelasan yang pasti mengenai patogenesis metastasis GCT of bone ke paru. Dilaporkan kasus giant-cell tumor of bone yang metastase ke paru pada perempuan berusia 51 tahun. Hasil diagnosis ditegakkan dari pemeriksaan sitologi pleura yang secara mikroskopik ditemukan adanya sel-sel bulat-oval, monomorf dengan sebaran sel-sel berinti banyak. Sebelumnya pasien mempunyai riwayat GCT yang didiagnosis 3 tahun yang lalu.

Kata kunci: giant-cell tumor of bone, metastase, paru

\begin{abstract}
Giant-cell tumor of bone (GCT) is a primary bone tumor that usually occurs in young adults, 20-40 years old. Giant-cell tumor of bone is benign but very destructive locally and has a very high recurrence. Metastasis to the lungs is very rare in giant-cell tumor of bone, with a prevalence of 1-9\% of all cases. There is no definitive explanation yet for the pathogenesis of metastasis giant-cell tumor of bone to the lungs. It was been reported a case of a 51-year-old female was diagnosed with giant cell tumor of bone metastatic to her lungs. The diagnosis was confirmed by pleural cytological examination, microscopically found round to oval cells, monomorf with multinucleated cells. This patient previously was diagnosed with giant-cell tumor of bone three years ago.
\end{abstract}

Keywords: metastase, ginat-cell tumor of bone, lung

Affiliasi penulis: ${ }^{1}$ Program Penddikan Dokter Spesialis Patologi Anatomi, Fakultas Kedokteran, Universitas Andalas, Padang. Bagian Patologi Anatomi, Fakultas Kedokteran, Universitas Andalas, Padang.

Korespondensi: Dutia Gestin, Email: dutiagestin84@gmail.com Telp: 082387507202

\section{PENDAHULUAN}

Giant-cell tumor of bone (GCT) adalah neoplasma primer pada tulang bersifat jinak. ${ }^{1}$ Angka kejadian GCT of bone 4-5\% dari semua tumor primer tulang. ${ }^{2}$ Insidensi puncak terjadi antara usia 20 tahun dan 40 tahun. GCT of bone jarang muncul pada anakanak (kurang dari $2 \%$ kasus) dan orang tua. GCT of bone lebih banyak pada perempuan dari pada laki-laki. Ditemukan $<1 \%$ GCT of bone yang bertransformasi menjadi ganas. ${ }^{3,4}$
Giant cell tumor of bone (GCT) terdiri atas proliferasi sel-sel mononuclear diantaranya tersebar sel-sel makrofag, dan osteoclast-like giant cells. ${ }^{1}$ Selsel mononuklear diantaranya bersifat reaktif dan nonneoplastik, tetapi pada beberapa kasus dapat bermetastasis jauh. ${ }^{4}$ Kejadian metastasis dapat dipengaruhi oleh rekurensi lokal. Secara umum GCT of bone bersifat lokal agresif, tetapi belum ada penjelasan yang pasti mengenai patogenesis metastase GCT of bone ke paru. ${ }^{3,4}$

Pembedahan merupakan salah satu terapi pada kasus ini. Pada kasus rekurensi lokal bisa terjadi karena komplit atau tidaknya reseksi tumor tersebut. Pada kasus yang tidak bisa dilakukan eksisi karena posisi anatomi yang sulit bisa diterapi dengan adjuvant. 3,4 , 
Sel-sel mononuklear terdiri dari dua jenis, baik prekursor osteoklas mirip makrofag yang pada akhirnya menunjukkan aktifitas mitosis dan mewakili komponen neoplastik GCT. ${ }^{5}$

\section{KASUS}

Seorang pasien perempuan berusia 51 tahun, datang ke RSUP M. Djamil Padang dengan keluhan batuk yang bertambah berat sejak dua minggu yang lalu. Kadang-kadang pasien merasakan sesak nafas. Riwayat penyakit terdahulu tiga tahun yang lalu pasien pernah menjalani operasi pengangkatan tumor pada vertebra Torakal XII sampai Lumbal I. Dengan diagnosis tumor berdasarkan pemeriksaan histopatologi giant cell tumour of bone.

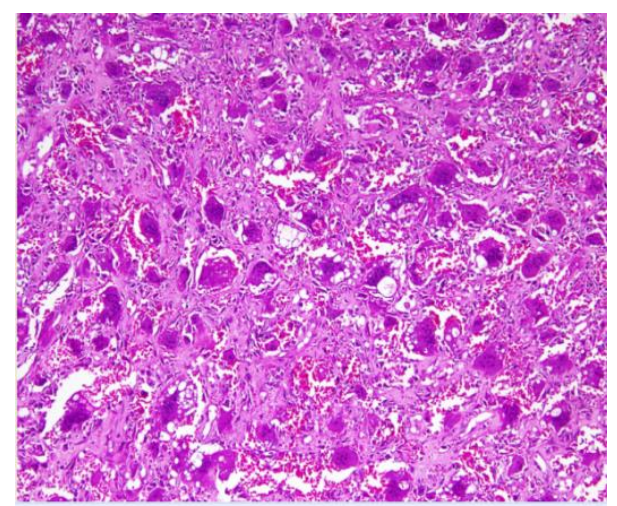

Gambar 1. Mikroskopik histopalogi pemeriksaan sebelumnya, tampak proliferasi sel-sel mononuklear serta sebaran osteoblast-like giant cells

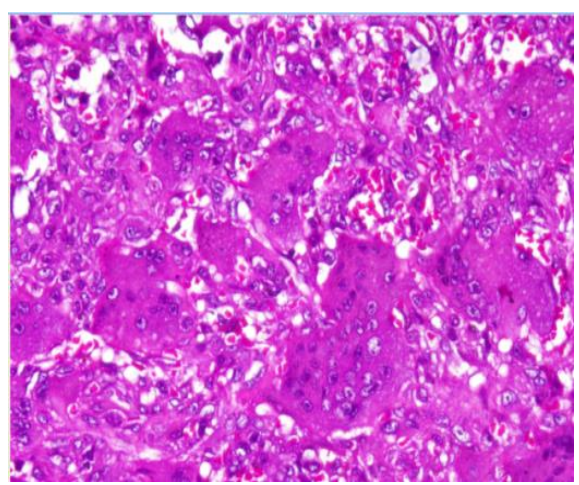

Gambar 2. Mikroskopik histopalogi pemeriksaan sebelumnya. Tampak osteoblast-like giant cells diantara sel-sel mononuklear dengan inti bulat-spindel.

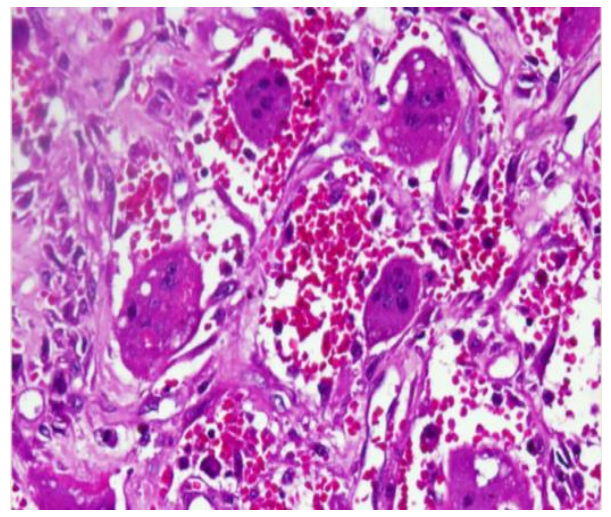

Gambar 3. Mikroskopik histopalogik pemeriksaan sebelumnya. Osteoblast-like giant cells menginvasi kedalam vaskuler.

Berdasarkan gejala klinik dan riwayat penyakit pasien terdahulu dilakukan pemeriksaan CT scan torak dan USG paru. Hasil pemeriksaan tersebut didapatkan diagnosis kerja suspek karsinoma bronkhogenik jenis sel belum diketahui, diagnosa banding: metastasis karsinoma vertebra ke paru. Selanjutnya pasien menjalani transthoracic needle aspiration (TTNA). Slide hasil TTNA dikirim ke laboratorium Patologi Anatomik. Hasil analisis secara mikroskopik tampak kelompokkan sel-sel bulat-oval, agak vesikuler, anak inti ada yang nyata. Tampak juga sebaran sel-sel berinti banyak. Kesan metastase giant cell tumour of bone ke paru.

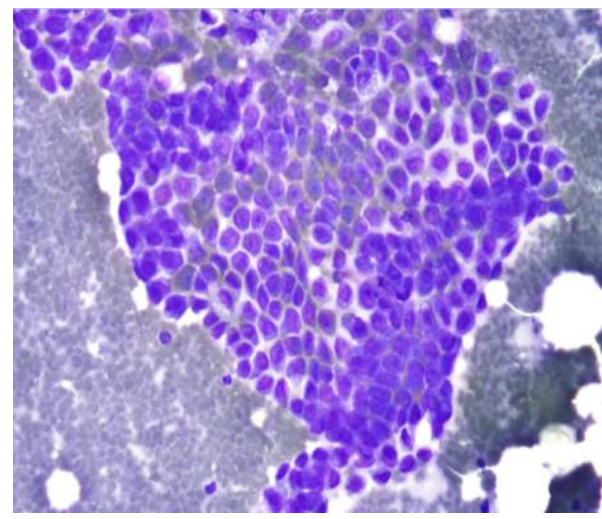

Gambar 4. Mikroskopik TTNA, tampak sel-sel bulatoval membentuk kelompokkan solid. 


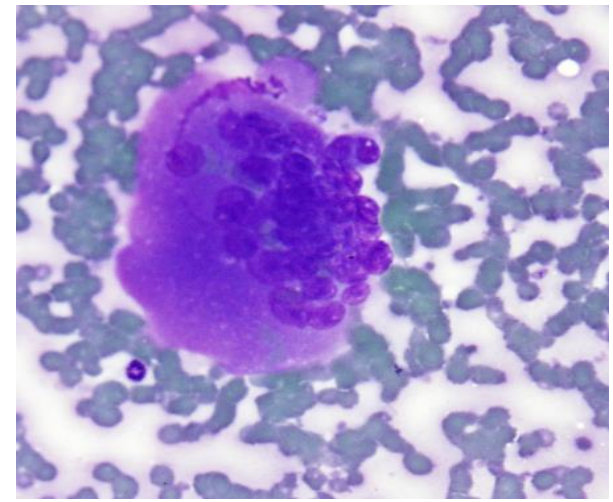

Gambar 5. Mikroskopik TTNA, tampak sel berinti banyak

\section{PEMBAHASAN}

Dilaporkan kasus metastase giant cell tumor of bone ke paru pada pasien perempuan usia 51 tahun. Riwayat pasien sebelumnya didiagnosis dengan giant cell tumour of bone.

Giant cell tumor of bone merupakan tumor primer tulang yang bersifat jinak dan agresif lokal. Usia puncak yang paling sering ditemukan adalah 20-40 tahun, jarang muncul pada anak-anak dan orang tua. ${ }^{6}$ Pada kasus ini, GCT of bone ditemukan usia 51 tahun. Laporan kasus Du et al (2014) memaparkan GCT of bone pada usia 57 tahun. ${ }^{7}$ Penelitian Deveci et al (2017) dengan hasil dari 12 pasien GCT of bone 2 diantaranya berusia 51 tahun dan 50 tahun. ${ }^{8}$

Pada kasus ini, GCT of bone muncul pada vertebra Torakal XII sampai Lumbal I. Lokasi tersering munculnya GCT of bone biasanya pada epifisis tulang panjang, distal femur, proximal tibia, distal radius dan proximal humerus. ${ }^{9}$ GCT of bone dapat ditemukan pada tulang belakang, namun kasus ini jarang ditemukan. Hasil penelitian Liu (2013) et al menyatakan bahwa dari 80 kasus GCT of bone, $1 \%$ ditemukan pada vertebra torakal dan $1 \%$ pada tulang lumbal. ${ }^{10}$ Pada penelitian Donthineni et al, ditemukan 51 kasus GCT of bone pada tulang belakang. ${ }^{11}$

Gejala klinik yang ditemukan pada pasien ini adalah batuk dan nyeri dada yang hilang timbul. Gejala klinik yang muncul sesuai dengan lokasi tumor tumbuh. Metastase GCT of bone ke paru tidak mempunyai gejala klinik yang khas, gejala klinik bisa asimptomatik, sesak nafas, nyeri dada, dan batuk. ${ }^{3}$ Laporan kasus Yadav et al (2012) melaporkan pasien GCT of bone pada paru menunjukkan gejala klinik nyeri dada, sesak nafas dan batuk. ${ }^{12}$ Berdasarkan laporan kasus Kadam et al (2018) gejala klinik yang muncul adalah nyeri dada dan sesak nafas. ${ }^{13}$ Pada penelitian Dominkus $M$ et al dari 649 kasus memiliki gejala klinik yang berbeda-beda, asimtomatik, sesak nafas, nyeri dada, dan batuk. ${ }^{3}$

Berdasarkan pemeriksaan mikroskopik sitologi TTNA menunjukkan adanya kelompokkan sel-sel bulat-oval, agak vesikuler, anak inti ada yang nyata serta adanya sebaran sel-sel berinti banyak. Berdasarkan gambaran mikroskopik diatas dibuat dengan kesan metastase giant cell tumor ke paru. Gambaran ini sesuai dengan kepustakaan bahwa secara sitologi tampak sel-sel berinti banyak (osteoclast-like giant cell) dan sel-sel mononuklear. Inti dari osteoclast-like giant cell sama dengan sel-sel mononuklear, dengan inti bulat-spindel, vesikuler, hiperkromatin, anak inti nyata, kadang ditemukan adanya mitosis. ${ }^{6,7,12}$

Giant cells memiliki banyak inti (20-50 inti) yang sama dengan inti sel-sel mononuklear. Sel-sel memiliki sitoplasma ampofilik, ada yang bervakuol, dengan batas sel yang jelas. Osteoclast-like giant cell bersifat non neoplastik tetapi merupakan suatu reaksi reaktif. ${ }^{14}$ Sel-sel mononuklear terdiri dari dua jenis, baik prekursor osteoklas mirip makrofag, atau sel-sel primitive mesenchymal stromal yang mengekspresikan receptor activator for NK-KB ligand (RANKL), yang pada akhirnya menunjukkan aktifitas mitosis dan mewakili komponen neoplastik GCT. Makrofag dan osteoklas mengekspresikan RANK dan dengan adanya faktor stimulasi dari kelompokkan makrofag, sel-sel stroma mononuklear yang berproliferasi menginduksi pembentukan osteoklas melalui mekanisme yang bergantung pada RANK. Sel-sel stroma mononuklear juga mengekspresikan (pre) osteoblast markers, termasuk alkaline phosphatase, RUNX2 and Sp7 transcription factor (osterix). 1,4,5 Pada laporan kasus Miller et al (2010), pasien dengan metastasis benign GCT ke paru. Secara mikroskopik lesi diparu identik dengan gambaran lesi awal GCT of bone. ${ }^{14}$

Metastasis ke paru lebih sering terjadi dibandingkan pada metastasis ekstrapulmoner. Lesi metastasis secara histologi identik dengan lesi primer. 
Interval rata-rata antara timbulnya tumor dan deteksi metastasis paru sekitar 1 hingga 2 tahun, kadangkadang bisa terjadi 10 tahun. ${ }^{7,12,15}$ Pada kasus ini ditemukan riwayat GCT of bone tiga tahun yang lalu dan muncul kembali setahun ini pada lokasi yang sama.

Penjelasan yang pasti mengenai patogenesis metastasis GCT of bone ini belum ada. Metastasis ini tumbuh sangat lambat dan dianggap perjalanan metastasis ini sebagai embolisasi intravaskular GCT of bone dari tumor primer. ${ }^{6,7} \mathrm{Hal}$ ini dapat terjadi selama pasien menjalani operasi dengan prevalensi mikroemboli tumor.6,7 Berdasarkan laporan kasus Yadav et al dan Liu $\mathrm{J}$ et al bahwa metastasis paru paling sering terjadi pada kasus GCT of bone yang berulang. ${ }^{10,12}$ Pada pasien ini ditemukan rekurensi setelah 3 tahun diagnosis pertama. Berdasarkan beberapa literatur tingkat kekambuhan lokal setelah eksisi dilaporkan bervariasi, antara $25 \%-50 \%$. Pada bebarapa kasus terapi adjuvant seperti radioterapi atau kemoterapi dengan pembedahan dapat menurunkan angka rekurensi $6 \%-25 \%{ }^{13,16}$

\section{SIMPULAN}

Mikroskopik lesi metastase identik dengan lesi primer. Pemeriksaan penunjang CT scan torak dan USG torak dilakukan pada pasien ini. Belum ada penjelasan yang pasti mengenai patogenesis metastase GCT of bone ke paru.

\section{UCAPAN TERIMA KASIH}

Terimakasih kepada Program Studi/Bagian Patologi Anatomik Fakultas Kedokteran Universitas Andalas. Laboratorium Patologi Anatomik RSUP. M. Djamil Padang yang telah memberikan kontribusi dalam kesempurnaan laporan kasus ini.

\section{DAFTAR KEPUSTAKAAN}

1. Reid R, Bagerjee SS, Sciot R. Giant cell tumour. In: WHO pathology and genetics of tumours of soft tissue and bone. 2013. France. Lyon.hlm.310-2.

2. Akerman $M$, Domanski HA, Jonsson K. Fine needle aspiration of bone tumours. In: The clinical, radiological, cytological approach. 2010. Switzerland. hlm.55-7.
3. Dominkus $M$, Ruggieri $P$, Bertoni $F$, Briccoli $A$, Picci $P$, et al. Histologically verified lung metastase in benign giant cell tumours-14 cases from a single institution. International Orthopaedics (SICOT). 2006.30:499-504.

4. Bacchini P, Bertoni F. Giant Cell Tumor of Bone. In: Bone and soft tissue pathology. 2010. Elsevier. Philadelphia: Elsevier.hlm.401-7.

5. Kharana JS, Mc Carthy EF. Giant cell lesion. In: Essential in bone and soft-tissue pathology. 2010. Springer New York: Springer..hlm.134-7.

6. Wang $\mathrm{H}$, Ningjun $\mathrm{W}, \mathrm{Hu}$ Y. Giant cell tumour of bone: a new evaluating system is necessary. International Orthopaedics (SICOT). 2012. 36: 2521-7.

7. Du H, Xu H, Che G. Malignant giant cell tumor of rib with lung metastasis in a man. $\mathrm{J}$ Thorac Dis. 2014.6(9):1307-10.

8. Deveci MA, Paydas S, Gonlüsen G, Ozkan C, Biçer OS, et al. Clinical and pathological results of denosumab treatment for giant cell tumors of bone: Prospective study of 14 cases. Acta Orthopaedica et Traumatologica Turcica. 2017:1-6.

9. Pantanowitz L, Michelow $P$, Khalabuss WE. Cytopathology of Infectious Disease. 2011. Springer. New York: Springer.hlm.135-7.

10. Liu J, Yang $H$, Sun $R$, Yang Z, Zhu Z. Retrospective analysis of patients with rare-site and metastatic giant cell tumor. Chin $\mathrm{J}$ Cancer Res. 2013;25(5):585-92.

11. Donthineni R, Boriani L, Ofluoglu O, Bandicia S. Metastatic behaviour of giant cell tumour of the spine. Int Orthop. 2009;33:497-501.

12. Yadav R, Bakhshi S, Mathur SD, TilakT, Singh G et al. Cytomorphology of giant cell tumor of bone in pleural fluid. Cytojournal. 2012;9:22.

13. Kadam SG, Bindroo S, Krishnan J, Shah HJ, Lele VR, et al. A very rare case of metachronous multicentric giant cell tumor of bone with benign lung metastasis in form of a very large mass lesion. J Cardiothorac Med. 2018;16(3):350-4.

14. Miller IJ, Blank A, Yin SM, Mcnickle A, Gray R, et al. A case of recurrent giant cell tumor of bone with malignant transformation and benign pulmonary metastases. Diagn Pathol. 2010;5:62. 
15. Sobti A, Agrawal P, Agarwal S, Argawal M. Giant cell tumor of bone- an overview. Arch Bone Jt Surg. 2016;4(1):2-9.

16. Yeo CD, Roh SY, Shin OR, Bahk WJ, Kim KH, et al. A case of pulmonary metastasis of giant cell tumor of bone presenting as pulmonary arteriovenous malformation. J Formos Med Assoc. 2012;114:369-72. 